anthropology \& materialism

\section{Anthropology \& Materialism}

A Journal of Social Research

$2 \mid 2014$

The Persistence of Myth

\title{
Roger Caillois' Biology of Myth and the Myth of Biology
}

La biologie du mythe et le mythe de la biologie chez Roger Caillois

\section{Rosa Eidelpes}

\section{(2) OpenEdition \\ 1 Journals}

\section{Electronic version}

URL: https://journals.openedition.org/am/84

DOI: $10.4000 / a m .84$

ISSN: 2364-0480

\section{Publisher:}

CETCOPRA, CRASSH - Center for Research in the Arts Social Sciences and Humanities, Fakultät Gestaltung - Universität der Künste Berlin

\section{Electronic reference}

Rosa Eidelpes, "Roger Caillois' Biology of Myth and the Myth of Biology", Anthropology \& Materialism

[Online], 2 | 2014, Online since 15 April 2014, connection on 21 September 2021. URL: http://

journals.openedition.org/am/84 ; DOl: https://doi.org/10.4000/am.84

This text was automatically generated on 21 September 2021.

Tous droits réservés 


\title{
Roger Caillois' Biology of Myth and the Myth of Biology
}

La biologie du mythe et le mythe de la biologie chez Roger Caillois

\section{Rosa Eidelpes}

\section{EDITOR'S NOTE}

English translation reviewed by Kevin Kennedy

\section{Introduction}

\author{
"Comparant les modèles les plus achevés des deux \\ évolutions divergentes du règne animal, évolutions \\ aboutissant respectivement à l'homme et aux \\ insectes, il ne devra pas paraître périlleux de \\ chercher des correspondances entre les uns et les \\ autres et plus spécialement entre le comportement \\ des uns et la mythologie des autres [...]." \\ Roger Caillois
}

1 The sociologist, writer, and literary critic Roger Caillois (1918-1978) devoted his oeuvre to a universal "phenomenology of the imagination". Caillois post-war books are based on his idea of a "natural fantastic" (fantastique naturel, cf. Caillois 1962) and explore the scientific field of mineralogy with a study about the Writing of Stones (French original 1975), or examines the logic of the imaginary in the phantasms and legends connected to the life of octopuses (1973). But the epistemological basis for his theory of a "aesthetic of nature" is already built in his very first writings: In the 1930ies, myth becomes a crucial object of Caillois analysis. It is portrayed as the "focal point of the imagination" (cf. 1938:9). According to Caillois, myth can therefore no longer be confined to the specialist area of a 
cultural analysis of mythology but becomes the object of a new, universal science, the basis of which Caillois begins to develop in the 1930s: this so-called "diagonal science" ( science diagonale; cf. 1960) cuts across the different branches of science, both methodologically and in terms of subject matter. His early book on myth, Le mythe et l'homme (1938), collects studies on Chinese royal myths, surveys on Greek mythology, myths on insects, such as the praying mantis, and urban myths in police novels from $19^{\text {th }}$ century Paris. Caillois thus combines literary and sociological studies, connects them to psychological and biological frameworks, and thereby already lays the ground for his concept of a diagonal science.

2 The following article focuses on the two chapters in Le mythe et l'homme, which deal with the mythology of insects, "La mante religieuse" (abbreviated version published in 1934) and "Mimétisme et psychasthénie légendaire" (abbreviated version 1935), in which Roger Caillois links mythology to entomology for the purpose of a "fundamental biological research" on myth. He thereby not only presupposes structural analogies between phenomena in the animal kingdom and human myths, but also assumes a process of direct reproduction of natural, biological laws in the human faculty of imagination. Caillois' mythology of the praying mantis thus exceeds the limits of a merely scientific methodological research and cannot be regarded as a straightforward examination of already existing myths. By drawing on assumed analogies between apparently disparate phenomena and various scientific epistemologies, Caillois, contrary to his intention, creates a quasi-mythical text himself. Still, my reading of Caillois' early essays on myth does not intend to dismiss his biologist mythology as simply pseudo-scientific, but considers it as a hybrid between fiction and science, and in this sense as epistemologically productive.

\section{Empirical Imagination}

3 Le mythe et l'homme is Caillois' first important work on myth and was published in $1938 .{ }^{1}$ The volume gathers several texts that had already been partly published in the early 1930s. Le mythe et l'homme aims to examine the "nature and functioning" of myth, as well as the different laws of its formation (cf. 1938: 13). Caillois' mythology is part of his approach to a "phenomenology of the imagination" that he had already initiated in his first writings, e.g. in Le procès intellectuel d'art (first published in 1935, cf. Caillois 1974a). From the study of myth Caillois expected a privileged starting point for the structural enquiry into imagination, as he considered myth to reveal both collective social ideas and the deep structures of the individual psyche:

C'est en effet dans le mythe que l'on saisit le mieux, à vif, la collusion des postulations les plus secrètes, les plus virulentes du psychisme individuel et des pressions les plus impératives et les plus troublantes de l'existence sociale. (Caillois 1938: 13)

4 Caillois' mythology thus aims firstly to explain the specific character of various manifestations of the imaginary, secondly to systematize these various phenomena that feed human myths, and finally to show how the independent elements are nevertheless interwoven with and tied to each other to form an "organic totality" of myth (une totalité organique, cf. ibid.: 12).

5 Although Caillois' interest in myths as well as the specific focus of his research - myth is examined in relation to the miraculous, the game, the dream, and psychopathology - 
reveal the significant influences surrealism and psychoanalysis had exerted on him, his systematic approach is very specific: his mythology does not want to analyse the content of myth, nor does it intend to provide any more "deliriums of content", but aims to proceed in a strictly formal manner (cf. ibid.: 19). ${ }^{2}$ His mythological project was not only preceded by studies (1933-1934) with the famous religious scientist and comparative mythologist Georges Dumézil at the École pratique des hautes etudes in Paris but also by a renunciation of surrealism in 1934. Disappointed by the "imbalance between science and art", he departed from the circle around André Breton and accused it of privileging art, and thus remaining in the realm of intuition and the irrational. Caillois by contrast does not want to content himself with a pure description of myth, or its evocation by means of art, but seeks to analyse it, and to classify and systematize its elements (cf. 1974b: 35-35). ${ }^{3}$

Even though his approach to mythology is strongly influenced by the methods of Freudian psychoanalysis, ${ }^{4}$ whose concepts of the unconscious and overdetermination he borrows for his own analysis, Caillois distances himself from the "blind and mechanical use" of psychoanalytical symbolism and elaborates his own theory of mental faculties (cf. ibid.: 23f.). According to Callois, an investigation of myth requires an analysis of that "special faculty of the mind", called the imagination. For him, this faculty does not constitute a pure or transcendental imagination but is rather based on the partie vécue, that is to say on the "impure" 5 and subjective elements taken from reality itself, "[...] les seuls matériaux sur lesquels on puisse utilement travailler à isoler le fait de l'imagination, en tant qu'activité diffluente [...]" (1974a: 49). In Caillois' epistemology, the imagination is an empirically grounded faculty, thus he refers to it as "empirical imagination":

L'impureté dans l'art relève enfin exclusivement de l'imagination empirique, en entendant par cette expression la capacité d'utilisation du concret à des fins les plus souvent passionnelles, mais où la part d'une certaine intellectualité tendue n'est nullement négligeable. (1974a: 47)

Although Caillois attaches a certain importance to the role of the intelligence in the process of perception, the preceding quote shows that he puts the main emphasis on the empirical nature of the imagination. For him, the imagination is essentially empirical, because it emanates from a direct confrontation with sensual phenomena (cf. 1981: 17). In contrast to Kant's transcendental aesthetic (cf. Kant 1998), Caillois' theory of the imagination does not include any mediating or synthesizing elements, such as Kant's apprehension for instance, but is generated directly and immediately. ${ }^{6} \mathrm{He}$ introduces the term "objective lyricism" (lyrisme objectif, cf. 1970:218) to refer to the quality of empirical objects and phenomena that arises from their form or content and exists independently from and outside of the human mind. He calls these phenomena "objective" and "lyrical" because they have the "capability to influence human affectivity in a direct way" (1938: 9), and enable the mind to realise specific "affective possibilities" (ibid.: 19). In this regard, sensual empirical phenomena are no longer secondary or mere external stimuli. For Caillois, the objective lyricism inherent in works of art as well as in natural objects, is the principle cause for and driving force behind the human imagination, which thus can be called "empirical". With reference to both the content and the manifestations of this empirical imagination, he speaks of "objective ideograms" (idéogramme objectif, cf. 1981: 29). But it is left undecided whether the notion of an "objective ideogram" refers to the natural object or phenomenon itself, or merely to the internal, psychic representation if, in other words, it refers to empirical reality that, driven by mechanisms inside the human psyche, produces spontaneous associations, representations and ideas (Caillois 1981: 48), or if "objective ideogram" is rather a term for the products of the imagination. ${ }^{7}$ 
On the one hand, Caillois calls all natural phenomena "objective" and "lyrical", which are able to (lyrically) evoke emotional reactions, even against the will of the perceiving subject (cf. 1981: 29). Such objective ideograms seem to mediate between the extra- and the intrapsychic world. On the other hand, Caillois refers to imaginary images and dreams as well, or, put differently, to the products of human consciousness. In any case, according to Caillois' notion of an empirical imagination, the capacity of the imagination to be spontaneously productive and to generate new ideas is very limited. He does not regard imagination as an a priori faculty, but rather, with reference to the surrealist concept of écriture automatique, as some kind of "automatic thinking" (pensée automatique, cf. 1981: 48) that is firmly rooted in the empirical reality of the nature that surrounds it. ${ }^{8}$

\section{Comparative biology}

8 Phenomena that appeal to human affects, impulses and drives and thus directly to man's biological conditioning are particularly suitable to become natural sources of lyrical objectivity (cf. 1938: 30). Such phenomena, which man observes in nature, "correspond" to his inner psychological and biological structures, and as a result give rise to the imagination and the creation of myths. In assuming that there is an archaic, biological substructure of human fantasy, Caillois concurs with the theory of evolution as outlined by Henri Bergson. In his book Deux sources de la morale et de la religion (1932), published just a few years before Caillois' study on myths, Bergson posits a close link between human imagination and basic animal survival instincts: Bergson argues that the products of human imagination are based on a so-called "fabulation function" (fonction fabulatrice) that constitutes both the human counterpart to animal instinct and its evolutionary development (cf. Bergson 1932: $56 \mathrm{f}$.) The fabulation function is no longer exclusively tied to instinct, but it is also not fully detached from it either. In religious myths for example, due to the fabulation function, instinct is still active but intellectually developed (ibid.: 59). According to Bergson myths serve as a form of drive satisfaction. They help to intellectually overcome the threatening parts of human existence such as the inevitability of death (cf. ibid.: 71). He thus considers human intelligence as a higher form of basic instincts, or rather as one possible shape instinct assumed in the course of evolutionary development. Bergson insists that the intelligence is still based on the same conditions as animal instinct and moreover, that it is still imbued with instinct (cf. ibid.: 64). He even refers to the fabulation function as a "virtual instinct":

Disons provisoirement que c'est de l'instinct virtuel, entendant par là qu'à l'extrémité d'une autre ligne d'évolution, dans les sociétés d'insectes, nous voyons l'instinct provoquer mécaniquement une conduite comparable, pour son utilité, à celle que suggèrent à l'homme, intelligent et libre, des images quasi hallucinatoires. (Ibid.: 60)

Human intelligence and animal instinct both derive from a basic, unifying force, the "vital impetus" (élan vital) which, according to Bergson, is the fundamental motor behind all life forms, and are thus portrayed as two different but closely related and still intertwined manifestations of the same biological conditions. Human imagination is located in-between the two different "evolutionary lines" of instinct and intelligence (cf. ibid: 66 f.).

It is obvious that Caillois' attempt to analyse the biological conditions of human myths on the basis of a "comparative biology" (biologie comparée, Caillois 1938: 70) is significantly 
indebted to Bergson's notion of the fabulation function. He employs Bergson's evolutionary model for his own study of myth while trying to refine it: ${ }^{9}$ Caillois imagines a natural and universal network of objective ideograms that "corresponds" to man's archaic parts and offers the pattern for myth-making (cf. Caillois 1938: 26). At the same time, he considers myth to be overdetermined, that is to say, it is derived from more than one source and its production proceeds from "outside to inside". The first level of mythmaking arises from the observation of phenomena like the lunar phases or the solar eclipses, which have inspired various mythic narratives throughout human history. Together with stories on historical or social events and special geographic characteristics, they constitute the external components of myth but do not themselves sufficiently impact human affectivity (ibid.: 20-21).

In order to explain the more powerful substructure of myths, Caillois invokes an "internal mythology" (mythologie interne, ibid.: 30 ) that originates in several objective ideograms provided by nature. This internal mythology is based on phenomena that are linked to man's natural instincts, partly for psychological, partly for biological reasons (cf. ibid.: 24). According to Caillois, myth-making is not a procedure of symbolizing nature, instinct or the drives, but rather results from a direct imprinting of nature in products of human imagination - a process, which corresponds to the explanatory model he had already introduced in his theory of objective ideograms. The basis for myth-making is thus provided by a process of unmediated and virtual representation of (animal) drives in the human psyche:

On peut alors retrouver la trame de leur [des mythes, R.E.] organisation [...] étant donné que la représentation remplace en des certains cas l'instinct et que le comportement réel d'une espèce animale peut éclairer les virtualités psychologiques de l'homme. (Ibid.: 33 )

By following Bergson's theory of evolution, and in contrast to the psychoanalytical theory of myths, ${ }^{10}$ Caillois does not assume social reasons but basic animal instincts, shared by both man and animal (insect), to be at the core of myth-making. Those stem from shared evolutionary origins, and the "relative continuity" of an evolutionary development that is grounded in the "homogeneity of the universe" (ibid.: 72). For this reason, Callois expects "comparative biology" to produce new insights into the structure and functioning of myths.

\section{Biology of the femme fatale}

The essay on the praying mantis is of great significance for Caillois' biological grounding of myth theory. His reflections on the assumed analogies between animal behaviour and human myth-making go back to the early 1930s, to his first book (unpublished during his lifetime) La nécessité d'esprit (1981, written somewhere between 1933 to 1935). An abbreviated version of "La mante religieuse" had been published in 1934 in the surrealist journal Minotaure, as well as his other early essay on imagination and insects, "Mimétisme et psychasthénie légendaire" (1935). Extended versions of both texts are included in the volume Le mythe et l'homme (1938), complete with references to entomological studies and extended to a full theoretical reflection on "comparative biology". The chapter on the praying mantis draws a comparison between myths and scientific research on the praying mantis on the one hand, and the myth of the femme fatale on the other. Caillois refers to myths, scientific reports, lexica and folk tales from the ancient world to the present time, 
from both European and non-European cultures, where the insect is associated with "all sorts of miraculous things". He has recourse to reports by natural scientists from the $19^{\text {th }}$ and $20^{\text {th }}$ centuries as well as to anthropological reports on North Asian, North American and Kabyle myths on female spectres that kill their males (cf. ibid.: 61 f.). He also cites a treatise on the nature of sexuality by the German Romanticist Novalis (ibid.: 58), and shows that nursery rhymes attribute fortune telling skills to the animal, and that, in French folk tales, it is believed to be a miracle healer (cf. 1938: 40-41). Rather additively, he strings together several quotes from the different texts and text genres to prove, that in Parma, Portugal as well as in Tyrol, Germany and Greece the insect was considered to be both satanic and sacred, whereas in Africa it is worshiped as a god. By quoting extracts from these different source materials, Caillois wants to draw attention to one of the insect's special characteristics: its tooth. The latter is used by the female praying mantis to kill and devour the male during copulation (ibid.: 46 f.). Caillois insists that the behaviour of the animal is the reason why man associated it with a dangerous, maneating female sexuality, and that in stories and reports on the insects, it conspicuously often displays characteristics that are usually attributed to a femme fatale (ibid.: $58 \mathrm{f}$.).

Caillois' particular interest in the praying mantis certainly is very à la mode at this time: Famous surrealists like André Breton owned and bred the animal. The insect was deemed an animal version of the femme fatale - a very popular surrealist figure that was both arousing and terrifying and gave rise to numerous myths about female magic, divinity and power. The insects fascinated the surrealists and Roger Caillois, not only because its posture seemed to correspond to its name and thus supposedly revealed a magic relationship between nature and religion, but also because of its aggressive sexual behaviour. Thus it became the surrealist symbol for female sexual domination (cf. Zuch 2004). Against this background, Caillois' text on the praying mantis raises the question if it is not the particular behaviour of the insect in the first place, that initially spawned the creation of myths on sexually dangerous women:

Ce qui m'a intéressé, c'est de voir qu'il y avait dans la mythologie des mythes qui n'avaient pas comme centre la mante religieuse, mais qui étaient des mythes des femmes fatales, ou de femelles dangereuses dont le vagin était denté, par exemple, et coupait l'organe masculin, ou détail empoisonné, communiquait une maladie pernicieuse à ceux qui s'accouplaient avec elles [...]. (Caillois 1991: 65)

15 For Caillois, the similarities between myths on femmes fatales and myths on the praying mantis, i.e., the analogies between human myths and myths referring to natural phenomena are not accidental. Nor does he believe that animal myths are mere projections of human fantasies onto phenomena of the animal kingdom. He rather insists that both mythologies have the same origin, namely the biological condition of all living creatures. The reasons for the similarities of the two mythological narrations are thus empirical and evolutionary (cf. 1938: 83).

16 To explain the presumed analogies, Caillois at first refers to his theory of objective ideograms. He argues that because of its name, its physiognomy and its behaviour, the praying mantis possesses the "objective capability to operate directly on affectivity":

Ainsi, indépendamment de tout mythe et sans préjuger d'eux, il est certain qu'un insecte comme la mante religieuse présente à un rare degré cette capacité objective d'action directe sur l'affectivité : son nom, sa forme, ses mœurs même, dès qu'on les connait, tout paraît concourir à ce résultat. (1938: 38)

17 As Caillois had already pointed out in his theoretical treatise on the objective lyricism of natural phenomena, he considers the process of the imagination to consist of an 
unmediated evocation of certain ideas, triggered by empirical phenomena, in this case by the praying mantis (cf. 1938: 37). Yet, he does not think that myth-making is simply based on a chain of associations between the two separate spheres of human psychic life and instinctive animal behaviour, created by the imagination itself. Instead, he considers the basis of the imagination and of myth-making to be a process of human identification with the animal, caused by its "anthropomorphic" appearance, which he regards as a "reliable source of influence" on human affectivity (cf. 1938: 49). The special attraction that the insect exerts on human fantasy is based on its posture, which resembles man's praying position, and on its ability to turn its head instead of averting its eye from its object of interest (cf. ibid.: 49-50). According to Caillois the insects' affective potency consequently does not spring from its (culturally determined) features such as the mysterious name (given to it by man) and the magic power (attributed to it by man), but from its curious shape itself, and especially from its sexual and eating behaviour, which gives birth to the myths in the first place (La mythologie à l'état de naissance cf. ibid.: 38-39). For Caillois the phantasms that cause myth-making seem to emanate from the empirical realm. In other words: it is the natural appearance of the praying mantis itself that directly and immediately affects human imagination. He thus refers to the praying mantis as an objective ideogram (ibid.: 37 ).

The insect furthermore has a strong effect on man because of profound "coincidences" between the human world and the animal kingdom. Caillois suggests that the female animal's habit to consume the male during copulation corresponds to some elements in human psychic life, which become apparent in the castration complex. ${ }^{11}$ Thus, nature is virtually "extended into human consciousness" (ibd.: 61):

[...] j'ai essayé de montrer, que certaines réactions et constellations affectives primordiales qu'on retrouve quelquefois chez l'homme qu'a l'état de virtualités, correspondent à des faits explicitement et couramment observables dans le reste de la nature. (1974a: 47)

Chez l'homme, à divers degrés, se laissent constater des imaginations, où il est aisé d'apercevoir comme la survivance ou le pressentiment de semblables drames : phantasmes répondant aux comportement d'autres espèces vivantes. (1938: 56-57)

The castration complex, which Freud considered to be based on socials norms, such as the fear of patriarchal power, is put down to biology: Caillois argues that (male) castration anxiety is a psychic residuum of archaic drives. The "original, intrinsic connection between nurture and sexuality" that, according to him, can be observed in the eating behaviour of the insect, is no longer actually realized in the human world, but still remains very powerful in man's psychic life (cf. 1938: 59). ${ }^{12}$ By observing the female praying mantis, man's fear of being castrated and devoured by the woman during the act of copulation is reactivated. The evolutionary traces of animal instincts in the human psyche thus provide the basis for the creation of myths. Myths are representations of fantasies, directly and spontaneously evoked (cf. 1934: 25). They replace the animal instinct within man, which can no longer be realized and thus comes to life only virtually (1938: 60). ${ }^{13}$

20 Nevertheless, the fantasies and myths of the mantis religiosa, analysed by Caillois, are initiated by the real and empirically observable behaviour of the animal, whereas the figure of the femme fatale is only a figment of man's imagination and thus a mere product of human culture. Caillois only incidentally notes this difference: "La mante dévore son male [...], l'homme imagine que des créatures féminines le dévorent après l'avoir attiré dans leurs bras" (1938: 72, emphasis mine). But although the difference between nature 
and culture is mentioned by Caillois, he does not deem it essential. Instead, he emphasises the point that the threatening female sexuality, which in both cases feeds the content of the myth, bears directly on human affectivity (1938: 60), and ascribes this power to the shared biological conditions of both man and insect. He thus considers the insect's "objective" and "lyrical" potency to be proven. What is important to Caillois is that in his theory, myths preserve the continuity of animal instincts, which man has, in theory at least, already overcome. This continuity is extended well into the symbolic realm. According to Caillois, man is still, to a large extent, subjected to the laws of biology, even though these laws are no longer acted out physically, but only virtually in the realm of the imaginary. Although human imagination is considered to be an instance of evolutionary progress, and myth-making a super-natural faculty, more advanced than animal instinct, Caillois does not consider myths to be an auto-creative processes of drive-sublimation. Besides, the fictional parts of myth are left aside. Myth for Caillois is not an attempt at a cultural adaptation of the world, but functions exclusively as mirror of nature. In the form of human fantasies, myths serve as nature's direct and unmediated virtual representations, based on the evocation of the imagination by the power of empirical phenomena, that reactivate the residuum of animal instinct in the human psyche. In Caillois' approach to a "biology of myth", what is usually defined as products culture, including myth, appears as extension of nature, as the virtual trace of drives in the human psyche.

\section{Myth, mimesis and mimétisme}

Summarizing Caillois' theory, one can say that products of the human imagination, such as myth, are based on the "affective necessity" to react to natural phenomena, and that this necessity springs from powerful archaic biological conditions (cf. 1938: 23). In other words, man still has to adapt his thinking and his imagination to the force of nature. At the origin of myth-making, Caillois presumes an instinctive impulse, which, in relation to the outside world, becomes a mimetic impulse. As we have seen in the theory of objective ideograms, the imaginary and hence also myth are linked to the need to respond affectively to the appeals of animal nature, because, due to evolution, man is still part of nature. Mythologies, including the myth of the femme fatale, are based on man's biologically determined and impulsive inclination to be affected by natural phenomena. Put differently, Caillois' mythology does not highlight myth's potential to create artificial worlds, but thinks of it as a mimetic imitation of nature. ${ }^{14}$

In a similar manner Theodor W. Adorno and Max Horkheimer, who, unlike Caillois, were rather critical towards myths, describe them as objectifications of an "iterating nature", whereby thinking both adapts itself to natural conditions and simultaneously appropriates nature (cf. Adorno/Horkheimer 2001: 23). At Walter Benjamin's suggestion, Adorno took note of Caillois' essay on the praying mantis as early as 1937 and reviewed it quite favourably (cf. Adorno 1994). He praised the non-symbolic, materialist dimension of Caillois' theory, "[...] daß Caillois die Mythen nicht in Bewußtseinsimmanenz auflöst, sie nicht durch 'Symbolik' verflacht, sondern auf ihre Wirklichkeit aus ist" (Adorno 1994: 276-77). Nevertheless, in a private letter to Walter Benjamin he harshly criticized the absence of historical consciousness in Caillois' biological mythology, "[...] die Naivetät" mit der Caillois "[...] zwar die historische Dynamik in die Biologie hereinzieht, nicht aber ebenso diese in die historische Dynamik" (ibid.: 277). Indeed, man's mimetic 
appropriation of nature, approvingly described by Adorno and Horkheimer cannot be found in Caillois" theory of myths. On the contrary, Caillois "cryptofascist belief in nature", as Adorno calls it in his letter to Benjamin (ibid.), also reduces the Aristotelian concept of mimesis to biology, where it is construed as a natural compulsion to imitate: This becomes even more obvious in his essay "Mimétisme et psychasthénie légendaire", where Caillois sketches his notion of mimetism (mimétisme). ${ }^{15}$

Mimetism is initially used to describe practices of assimilation and camouflage in flora and fauna, such as the imitation of one species by another. But Caillois does not share the assumption of Darwinist evolutionary biology that mimetism is a survival strategy, nor that the imitation is necessarily useful, on the contrary: he argues that the animal's mimetism not only fails to protect it but that it can in fact be the principle cause for being eaten by its natural enemies (cf. 1935: 7). Thus, the reason for mimetism is not selfprotection, but a rather futile and instinctive pursuit of "assimilation to the environment" and a "spatial temptation", that can by classified as a "disturbed external and self perception" (ibid.: 7-8). In opposition to Darwin's theory of adaption through natural selection, Caillois argues that mimetism is of no use for the conservation of species and therefore a superfluous sport of nature (luxe dangereux, cf. 1935 7). ${ }^{16}$ Moreover, he does not limit mimetism to fauna and flora, but connects it to forms of human psychopathology, namely to "psychasthenia", as described by Pierre Janet in the $19^{\text {th }}$ century (cf. Janet 2005), where the patient feels lost in space and dissociated from himself (cf. Caillois 1935: 9). Mimetism and psychasthenia are coterminous with depersonalisation by overassimilation, and the blurring of boundaries between subject and environment. For Caillois, mimetism cannot therefore be attributed to survival strategies, but only to a symbiotic desire that drives the organism to self-destruction and must thus be viewed as a product of the death drive: „Un tel penchant méritait véritablement le nom d'instinct de mort“" (1938: 78).

Considering his theory of mimetism, we can stress another dimension in Caillois' explanation of the myths on insects: in contrast to Henri Bergson, who links myth to the vital impulse and emphasizes its utility for survival, Caillois relates mythic narration to pathological processes in nature. In this respect he does not appeal to Bergson, but to Freud, connecting mimetism not to the élan vital but to the death drive - the natural wish to return to inanimate, inorganic nature that ultimately leads towards self-destruction. ${ }^{17}$ Mimetism is thus based on the death drive. Caillois believes that the death drive, which he considers to be a pathological human impulse, causes both mimetic and symbiotic desire in human sexuality (cf. 1934: 26; 1938: 77-82, cf. 1938: 121). He argues that myths of lethal female sexuality remind man of his desire for and fear of dissolution, and that they are in fact evoked by it. According to Caillois, these fears and desires are rooted in the death drive and come to light in human psychopathology, as well as in the mimetism of insects and in virtual manifestations such as myths: „[...] [les] déterminations fondamentales [...] agissent[...] également dans les mythes et les délires, pour prendre le pôles extrêmes de l'affabulation" (ibid. : 84). The self-destructive mimetic impulse is thus held responsible both for the content of the myth of (human and animal) femmes fatales (that topically links fatal female sexuality and death) and for its formal creation. It is this natural mimetic impulse that engenders the human mind's instinctive response to nature's objective lyricism and overwhelms him through the power of objective ideograms. 
It is therefore no coincidence that the two essays on the praying mantis and on mimetism and psychasthenia, which were first published separately, are included in Le mythe et l'homme as two consecutive chapters in the section "The myth and the world" (le mythe et le monde, cf. 1938: 35). The essays are related not only because of their entomological subject matter, but also because both approach the empirical and biological dimensions of myths. The theory of objective ideograms, used by Caillois in his text on the praying mantis, as well as his notion of mimetism, both postulate a direct and overwhelming force of nature that forces the living being, man or insect, to renounce his/its survival instinct and surrender his/its affective balance to the arousing and at the same time threatening power of natural phenomena. If man, by the means of myth-making and the imagination, practices "mimetism in relation to nature", this is not in order to overcome or tame his animal instinct, nor due to survival impulses. For Caillois, the imagination and mythmaking are of little value for the mastery over or appropriation of nature, but rather represent its dangerous and superfluous parts. Myth emanates from the desire to be confronted with nature's nightmares, its deformations and "perversions" (1938: 57 f.).

\section{Myth and science}

Caillois' essays on the mythology of insects found a diverse readership and were not only criticized by Adorno. In relation to his "analogical thinking", Anne-Élisabeth Halpern (1999) and Vincent Fleury, for example, (2000) discuss Caillois' "demon of analogy", that introduces a system of classifications based on false or made-up analogies - a concept, which, according to Halpern, possesses a certain "poetical efficiency", but lacks a "rational scientific basis" (1999: 174 f.). Halpern argues that the similarities in mythic narrations and natural phenomena are produced artificially, not least by citing dubious scientific sources (ibid.: $161 \mathrm{f}$.). Indeed, Caillois text on the praying mantis shows little interest in the specific historical conditions for the creation of myths, but rather strings together documents from various historical and cultural areas, without actually differentiating between scientific, literary or traditional sources, and finally assembles them into a "nomenclature" that is supposed to prove the assumed analogies (cf. 1938: 51). The correspondences between natural phenomena and cultural or artistic products, which Caillois aims to reveal, are partly produced by his textual techniques.

From a strict scientific perspective, the criticism levelled at the made-up or fictional parts in Caillois' procedure of diagonal science is certainly warranted. But it falls short in that it exclusively regards Caillois' mythology as a scientific project in the classical sense. For it is not only the scientific gesture of his essays, but perhaps also their original, unorthodox and almost literary dimension, or to put it with Halpern, their "poetic efficiency", i.e., their fictional and fantastic character, that fascinates Callois' readers. ${ }^{18}$ The text on the praying mantis is, against his own claims, not a mere scientific analysis of myths, but rather seems to produce a new "mythology", that is to say it deliberately produces new, unexpected and imaginative relationships between castration anxiety, human psychopathology and phenomena of the animal kingdom itself. ${ }^{19}$ At the same time, as he tries to create a "scientific" basis for his fascination with the insect, he also provides the huge mythical complex of surrealist fantasies about the praying mantis with new phantasms. And because is not always clear whether Caillois merely points out correspondences, or if he actually produces them, whether he just diagnoses analogies or if he imagines them, he formally produces a "material mysticism". ${ }^{20}$ Thus, although he 
distances himself from surrealism, Caillois can be subsumed into the tradition of modern myth-making (mythologie moderne), starting with Louis Aragon. According to Peter Bürger (1971), this tradition can be characterized by its surrender to sensual perception and its desire to perceive new and different relations in the world beyond the realm of purposive rationality. Caillois' unconventional combination of entomology and aesthetic theory, and his emphasis on analogies between instinctual behaviour and human culture betray such a will to produce new, non-utilitarian relations. It is thus possible to interpret his mythology not only as an exemplary study of comparative biology and a natural-scientific approach to myth. Caillois' early texts on the insect-myths can also be read as an approach to epistemology and a poetic project or both at the same time: It can be interpreted as well as an essay on aesthetic perception and as a poetic text that uses textual strategies to playfully stage common images and fantasies about the femme fatale in order to make its reader shiver., His mythology oscillates between and draws on both science and fiction. By doing so, Caillois' reorganisation of mythology also revises scientific concepts and paradigms of evolutionary theory that had already passed its peak or had been excluded from the dominant scientific discourse such as a Lamarckist notion of adaptive force, ${ }^{21}$ and applies them to philosophical and aesthetic issues. His theory of useless mimetism is inspired by (and more or less contemporary with) life sciences and evolutionary theory, whose concepts are processed into an anthropological notion of artistic mimesis and used to interpret the mechanisms of myth-making. ${ }^{22}$ In adopting a position at the edge of a legitimate scientific discourse, Caillois' "comparative biology" is able to reveal the implicit mechanisms of science, its systems of classification, its mechanism of inclusion and exclusion, and thereby calls them into question (see Cha 2010: $17 \mathrm{f}$.). It is precisely because they deny disciplinary boundaries that Caillois' essays are able to transcend the limits of science and to test the implications of evolutionary biology for art and aesthetics.

One also has to point out the contemporary historical index of Caillois' comparative or diagonal biology, which combines mythology and natural-scientist paradigms in one text. This approach to a new scientific culture reflects the institutional crisis of the Lettres and the rising dominance of positivism in France (cf. Lepenies 2006: 90-102), which is concomitant with a "crisis of literature" diagnosed by Caillois (cf. 1974a: 53-54). By adopting the apparently more objective criteria and paradigms of the empirical sciences, Caillois seeks to authorize his own, humanistic cultural studies on myth, and to overcome surrealism's exclusive and, in his opinion, powerless concentration on art (cf. ibid.). Through his theory of empirical imagination, Caillois wants to take the plunge out of the "art for art's sake" into science, and out of literary mythology into a more empirical form of myth theory. But even though he criticizes literature and art as naive, metaphysical and powerless (cf. ibid.: $52 \mathrm{f}$.), he does not simply want to abolish it. His approach to myths rather seems to seek a new, empirically based aesthetic theory and thus, with the help of the natural sciences, to make the realm of aesthetics more respectable than the avant-garde and their claim for artistic autonomy was able to do:23 The notion of mimesis is part of a non-determinist view on evolution that does not confine aesthetic freedom to the realm of art, but assumes that nature itself is driven by anti-utilitarian mechanisms. Caillois argues that the animal, by adapting to its environment, does not act according to the dictates of survival, but, just like humans, according to an artistic freedom and on the basis of a sumptuous creative principle in nature itself. Thus, even though his theory of empirical imagination at first sight seems to reduce the imagination and creativity to fundamental laws of nature, his notion of mimetism also makes clear that he ascribes 
freedom of creativity to nature itself. His mythology does not only aim at a biological foundation for myth theory, but also at an artistic grounding of biology. In his later texts on the beauty of nature such as Ésthétique généralisée (1962) and Méduse \& Cie (1960), Caillois takes up this argument and sketches a vision of a universal and "natural" aesthetics and poetics, a "natural fantastic", rooted in nature itself. Not man, not the perceiving subject is the centre of aesthetic experience, but in the processes of imagination, the artistic principle of nature (nature artiste, Caillois 19 are realised independently from the human mind and will. In processes of aesthetic perception, the subject mentally collapses, identifies with the outside world and merges with its environment. Man is no longer the centre of the universe (cf. Jenny 1992: 64).

Thus it can be summarized that on the one hand, Caillois tries to revitalise the realm of aesthetics and the imagination by drawing on seemingly more objective biological paradigms. On the other hand, he also turns concepts of evolutionary biology upside down and reorganizes them - namely according to aesthetic criteria. Hence his theory of myth can also be read - and maybe even at least partially against its own intention - as an artist's plea for a new aesthetic theory that grounds artistic freedom and aesthetic autonomy in nature itself, and thus appeals to an almost unassailable ontological foundation. But whether it is science or fiction, Caillois' mythology prefigures highly topical questions about the possible connections between biology and aesthetic theory, beyond a Darwinist explanation of natural beauty on the basis of selection and reproduction. ${ }^{24}$ Despite the historical index of his essays and maybe even because of its unorthodox scientific methodology which is inimical to leading evolutionary paradigms of the $20^{\text {th }}$ and $21^{\text {th }}$ century, Caillois' approach to a biology of myth is still an inspiring incentive to further pursue analyses of the links between evolutionary and aesthetic theory.

\section{BIBLIOGRAPHY}

Adorno, T. W. 1986. Roger Caillois, La Mante religieuse. Recherche sur la nature et la signification du mythe. Paris: La Maison des Amis des Livres 1937 (book review). In Vermischte Schriften II. Gesammelte Schriften Bd. 20-31. (ed.) R. Tiedemann. Frankfurt on the Main: Suhrkamp, 229-230.

Adorno, T. W. 1994. Wiesengrund-Adorno an Benjamin, London, 22. 9. 1937. In Theodor W. Adorno und Walter Benjamin. Briefwechsel 1928-1940. Vol. 1. (ed.) The Theodor W. Adorno Archiv. Frankfurt on the Main: Suhrkamp, 276-277.

Bachelard, G. 1983. Le nouvel esprit scientifique (1934). Paris: Quadrige / P.U.F.

Bachelard, G. 1985. La psychanalyse du feu (1938). Paris: Gallimard.

Becker, A. et al. (ed.). 2008. Mimikry. Gefährlicher Luxus zwischen Natur und Kultur. Schliengen: Argus.

Bataille, G. 1946. L'économie à la mesure de l'univers. Paris: Gallimard.

Bergson, H. 1932. Deux sources de la morale et de la religion. Paris: Alcan. 
Berz, P. 2005. Die vier Verschiebungen des Blicks. In Blümle, C. and von der Heiden, A. (eds.). Blickzähmung und Augentäuschung,183-216.

Berz, P. 2008a. Biologische Ästhetik. (A)Symmetrie und (Un)Sichtbarkeit im Erscheinen des Bauplans. In Trajekte 17/9. October, 17-24.

Berz, P. 2008b. Die Kommunikation der Täuschung. Eine Medientheorie der Mimikry. In Becker et al. (eds.). Mimikry. Gefährlicher Luxus zwischen Natur und Kultur, 27-44.

Blümle C. and von der Heiden, A. (eds.) 2005. Blickzähmung und Augentäuschung. Zu Jacques Lacans Bildtheorie. Zurich, Berlin: Diaphanes.

Bohrer, K. H. 2007. Mythologie et non révolution. In Asholt, W. and Siepe, H. T. (eds.). Surréalisme et politique. Politique du surrealism. Amsterdam / New York: Rodopoi, 45-56.

Bürger, P. 1971. Der französische Surrealismus. Studien zum Problem der avantgardistischen Literatur. Frankfurt on the Main: Athenäum.

Caillois, R. 1934. La Mante religieuse. In Minotaure, 5, 23-26. English translation: Mimicry and Legendary Psychasthenia. In Frank, C. (ed.). The Edge of Surrealism, 89-103.

Caillois, R. 1935. Mimétisme et psychasthénie légendaire. In Minotaure, 7, 4-10. English translation: The Praying Mantis: From Biology to Psychonalysis. In Frank, C. (ed.). The Edge of Surrealism, 66-81.

Caillois, R. 1938. Le mythe et l'homme. Paris: Gallimard.

Caillois, R. 1950. L'homme et le sacré (1938). Paris: Gallimard. English translation: Man and the Sacred (1960). (tr.) M. Barash. Glencoe, IL: Free Press.

Caillois, R. 1960. Méduse et Cie. Paris: Gallimard.

Caillois, R. 1962. Esthétique généralisée. Paris: Gallimard.

Caillois, R. 1970. Intervention surréaliste. In Cases d'un échiquier. Paris: Gallimard, 209-222.

Caillois, R. 1973. La pieuvre. Essai sur la logique de l'imaginaire. Paris: La table ronde.

Caillois, R. 1974a. Approches de l'Imaginaire. Paris: Gallimard.

Caillois, R. 1974b. Lettre à André Breton (1935). In Approches de l'imaginaire (1974). Paris:

Gallimard, 35-38. English translation: Letter to André Breton; Literature in Crisis. In Frank, C.

(ed.). The Edge of Surrealism, 59-65; 84-86.

Caillois, R. 1975. Pierres réfléchies. Paris: Gallimard. English translation: The Writing of Stones (1985).

(tr.) B. Bray. Charlottesville: University Press of Virginia.

Caillois, R. 1978. La querelle des Haricots sauteurs. In Rencontres. (ed.) B. Didier. Paris: P.U.F., 290-294.

Caillois, R. 1981. La Nécessité d'esprit. Paris: Gallimard. English translation: The Necessity of Mind (1990). (tr.) M. Syrotinski. Venice, CA: Lapis Press.

Caillois, R. 1991. Worms Jeannine, Entretiens avec Roger Caillois. Paris: La Différence.

Cha, K-H. 2010. Humanmimikry. Poetik der Evolution. Munich: Fink.

Chaperon, D. 1992. Sémantique de la mante. In Jenny, L. (ed.). Roger Caillois. La pensée aventurée. Paris: Belin, 33-50.

Cheng, J. 2009. Mask, Mimicry, Metamorphosis. Roger Caillois, Walter Benjamin and Surrealism in the 1930s. In Modernism/Modernity, 16/1, 61-86. 
Durkheim. E. 1960. Les formes élémentaires de la vie religieuse (1912). Paris: P.U.F.

Fleury, V. 2000. Le démon de l'analogie. In Europe : revue littéraire mensuelle, 78, Roger Caillois, 196-209.

Frank, C. (ed.) 2003. The Edge of Surrealism. A Roger Caillois Reader. Durham and London: Duke University Press.

Freud, S. 1972. Die infantile Genitalorganisation (1923). In Studienausgabe. Vol V. (ed.) A.

Mitscherlich, A. Richards, and J. Strachey. Frankfurt on the Main: Fischer, 235-241.

Freud, S. 2000a. Jenseits des Lustprinzips. In Studienausgabe. Vol 3, Psychologie des Unbewußten. (ed.) A. Mitscherlich, A. Richards, and J. Strachey. Frankfurt on the Main: Fischer, 213-272.

Freud, S. 2000b. Totem und Tabu. In Studienausgabe. Vol. 9: Fragen der Gesellschaft, Ursprünge der Religion. (ed.) A. Mitscherlich, A. Richards, and J. Strachey. Frankfurt on the Main: Fischer, 287444.

Geble, P. 2011. Der Mimese-Komplex. In Ilinx, 2, Mimesen, 185-195.

Janet, P. 2005. Les obsessions et la psychasthénie (1903). 2 Vol. Paris: l'Harmattan.

Jenny, L. 1992. Roger Caillois : esthétique généralisée ou esthétique fantôme?. In Littérature 85, 59-73.

Kant, I. 1998. Philosophische Bibliothek. Vol. 505, Kritik der reinen Vernunft. Nach der 1. und 2. Originalausgabe, mit einer Bibliographie. Hamburg: Meiner.

Halpern, A-E. 1999. La taupe de l'analogie qui se croyait un papillon: Roger Caillois et la biologie animale. In Courtois, J-P. and Krzywkowski, I. (eds.). Diagonales sur Roger Caillois. Syntaxe du monde, paradoxe de la poésie. Paris: Improviste, 161-186.

Horkheimer, M. and Adorno, T. W. 2001. Dialektik der Aufklärung. Philosophische Fragmente. Frankfurt on the Main: Fischer.

Lacan, J. 1973. Le Séminaire. 11. Les Quatre Concepts fondamentaux de la psychoanalyse. (ed.) J-A. Miller. Paris: Éd. du Seuil.

Lepenies, W. 2006. Die drei Kulturen. Soziologie zwischen Literatur und Wissenschaft. Frankfurt on the Main: Fischer.

Menninghaus, W. 2011. Wozu Kunst? Ästhetik nach Darwin. Frankfurt on the Main: Suhrkamp.

Nitsche, J. 2008. Spiele mit der Sichtbarkeit. Mimétisme und mimetisches Vermögen nach Roger Caillois und Walter Benjamin. In Becker et. al. (eds.). Mimikry, 74-91.

Richman, M. 1988. Introduction to the Collège de Sociologie: Poststructuralism before its Time? In Stanford French Review 12/ 1, spring, 79-95.

Roy, J-M. 2002. Logique de l'imaginaire et sciences de l'homme. In Laserra, A. (ed.). Roger Caillois. Fragments, fractures, réfractions d'une oeuvre. Paris: P.U.F., 19-46.

Siegert, B. 2005. Der Blick als Bildstörung. Zwischen Mimesis und Mimikry. In Blümle, C. and von der Heiden, A. (eds.). Blickzähmung und Augentäuschung, 103-126.

Vogl, J. 1997. Für eine Poetologie des Wissens. In Richter, K., Schönert, J., and Titzmann, M. (eds.). Die Literatur und die Wissenschaften 1770-1930. Stuttgart: Metzler, 107-127.

Wulf, C. 1989. Mimesis. In Gebauer, G., Kamper, D., and Lenzen, D. (eds.). Historische Anthropologie. Zum Problem der Humanwissenschaften heute oder Versuche einer Neubegründung. Reinbek b.

Hamburg: Rowohlt, 83-125 
Zuch, R. 2004. Max Ernst, der König der Vögel und die mythischen Tiere des Surrealismus. In kunsttexte.de, 2, 1-13.

\section{NOTES}

1. Le mythe et l'homme is followed by other, more sociological or anthropological studies on myth, cf. i.a. Caillois 1950.

2. The approach to a "phenomenology of the imagination" was significantly inspired by Gaston Bachelard's Le nouvel esprit scientifique (1938). Caillois adopts Bachelard's call for a reformation of science and he also shares his emphasis on the experimental and imaginative parts in the process of scientific theory-production.

3. For more information on the quarrel between Breton and Caillois, which began with the famous "incident of the Mexican jumping beans" (Breton wanted to admire the beans from the outside, Caillois to open and dissect them), cf. Caillois 1978.

4. Caillois understands mythical narrations as an intersection of forces that spring from two different sources, from social structures and from the texture of the human psyche. He employs the concepts of overdetermination, transfer, and concentration that Freud had developed in his theory of the dream work, and praises the "worth-while logic of affective imagination" that "sheds light on the deep psychological reality" of myths (cf. 1938:23).

5. Besides the „impure“ elements in art, there is, according to Caillois, also a "pure", idealistic and harmonic part, of which he rather disapproves, however. In this context, he refers to the universal dualism of the sacré pur and the sacré impur of French religious sociology (cf. i.a. Durkheim 1960).

6. Considering its direct, anti-idealistic and material dimension, Caillois notion of „empirical imagination" remindes once more of Gaston Bachelard, who - but apparently only in 1938, that is to say after Caillois' early texts on empirical imagination - claims that the artist „material imagination" (imagination matérielle) springs from the encounter with matter, more precisely: with one of the for elements fire, water, earth or air. (Cf. i.a. Bachelard 1985.) Hower, in his book L'incertitude qui vient des rêves (1956), Caillois criticizes Freuds interpretation of dreams, arguing that there is no definitive criterion to tell dreams from reality.

7. Hence he eventually blurs the boundaries between the subject and the environment - a way of thinking that is intended by Caillois and is explicated in his theory on the mimetic faculty (cf. my remarks below).

8. Nevertheless, the imagination is not a simple imprint of a natural phenomenon (as in Descartes' theory of perception). Ideograms are complex and overdetermined. Caillois considers them to be an intersection of more then one empirical source. Moreover, he is especially interested in the deformations of the imagination (l'art impur) and in the deformations of nature itself (see my explications below). Hence, the ideogram always exceeds nature, and in this sense is rather related to natural „perversions“ (cf. Roy 2002: 29).

9. In a similar fashion Caillois writes: "[...] dans les mythes, ou précisément les instincts peuvent prendre les satisfactions que la réalité leur refuse, les hommes connaissent des situations semblables [...] chez l'homme la fonction fabulatrice tentait justement le rôle du comportement instinctif chez l'insecte" (1938: 83). But he distances himself from Bergson's finalistic approach that only attributes a conserving function to myths (ibid.: 72). Unlike Bergson, Caillois is more interested in "morbid" myths like the femme fatale, and the transgressive functioning of myths (see my explanations below).

10. Freud considers myth to arise from the veiling and restaging of the original patricide, committed by the primal horde (cf. Freud 200a). 
11. According to Freud, in the course of a (male) child's development, the discovery of sexual differences, together with incestuous desires towards the mother, give rise to the fear of being castrated by the father (cf. Freud 1972).

12. Nevertheless, Caillois does not only appeal to mere psychic residuums of animal drives: With reference to the cultural practice of the "love bite“, he imagines that the female desire to devour her male partner during coitus actually still really exists: "[...] il existe un lien biologique primaire, profond, entre la nutrition et la sexualité; ce lien aboutit dans un certain nombre d'espèces animales à faire dévorer le mâle par la femelle à l'instant du coït; il subsiste chez l'homme des traces notables de cette parenté ou convergence d'instincts." (1938: 60). In the same context, he ascribes a special affinity for such instinctive behaviour to "primitive" and "wild" women. For a critical discussion of Caillois' primitivism (and racism), cf. Chaperon 1992 : 34-35.

13. Moreover, the "objective lyricism“ of the praying mantis is intensified by the death drive (cf. Freud 2000b): "En effet, l'assimilation de la mante à un automate, c'est-à-dire, vu l'anthropomorphisme de cette dernière, à un androïde féminin, me paraît relever du même thème affectif, pour peu que, comme j'ai par ailleurs toutes raisons de penser, la conception de la femme-machine, artificielle, mécanique, inanimée et inconsciente, sans comme mesure avec l'homme et les créatures vivantes, dérive d'une façon particulière d'envisager les rapports de la mort et de l'amour, et plus précisément d'un pressentiment ambivalent de trouver l'une dans l'autre." (1934: 25-26) On the "anthropomorphism" of insects and the similarities between the human death drive and animal mimetism, see my explications below.

14. Whereas mimesis, as Aristotle defines it, cannot be described as a simple reproduction (representation), because it always contains the potential to generate new forms or ideas.

15. On the etymological differences between the French term mimétisme (generally referring to homomorphic organisations) and the English notion of „mimicry“ (according to Bates: insect assimilation), cf. Geble 2011. On the theory of mimicry or mimetism in Caillois, cf. Cheng (2009), Cha (2010), and several contributions in the volume Mimikry. Gefährlicher Luxus zwischen Natur und Kultur (Becker et al. 2008), especially those of Peter Berz and Jessica Nitsche.

16. The idea of a "sumptuous luxury“ in nature certainly owes a lot to his friend and companion Georges Bataille, who in his manifold writings on culture, religion, economy and philosophy draws on the anti-utilitarian principle of „unproductive expenditure“ (cf. i.a. Bataille 1946).

17. Cf. Freud 2000a. „Il convient enfin de ne pas passer sous silence le mimétisme des mantidés, qui illustre de façon quelquefois hallucinante le désir humain de réintégration à l'insensibilité originelle, qu'il faut rapprocher de la conception panthéistique de la fusion dans la nature [...]." (1934: 26)

18. One of Caillois' readers is Jacques Lacan, who, in his concept of the mirror stage, refers to Caillois' theory of mimetism, cf. Lacan 1973; Berz and Siegert 2005.

19. According to Karl Heinz Bohrer (2007), the invention of new mythologies (by using "imaginative vocabulary" and a "metaphoric style") is one of the key characteristics of surrealism, which in that respect is connected to the Romantic "New Mythology“ (Schlegel). Thus, it can be argued that Roger Caillois still is part of the surrealist tradition of a „Modern Mythology", although he distances himself from the surrealist movement.

20. Caillois' own diagnosis of his early writings, given in Pierre réfléchies (1975).

21. For an approach to Caillois' references to Lamarck, cf. Kyung-Ho Cha 2010. According to Cha, Caillois is historically located in a phase of scientific rebuilding, where "scientific myths" of mimicry were in great demand (cf. Cha: 17 f.). Cha indicates that Caillois' notion of mimetism appeals to Lamarckist theories of adaption through the influence of the environment and at the same time points out that "[...] Caillois' Theorie gegen die darwinistische Mimikryforschung und gegen jene Wissenschaftsideale auf[begehrt], die während der Krise der Mimikryforschung für den Ausschluss der Einbildungskraft aus der wissenschaftlichen Forschung plädierten." (2010: 88). According to Cha, one could also say that theories that have already passed the climax of 
their validity or never reached it, sometimes find an "afterlife“ in aesthetic theory or are incorporated in a „scientific myth“ (cf. Cha, ibid.)

22. In his essays Caillois quotes, amongst others, Jean-Baptiste Lamarck, the evolutionary scientist Felix LeDantec and the biologist August Weissman. He thus refers to a specific scientific discourse, dating from around 1900 that cannot be elaborated in this text but is examined by Cha (2010) and Berz (2008a), amongst others.

23. Moreover, the approach to a biology of myth has to be understood as an early critique of anthropocentrism in the sciences humaines, which Caillois seeks to overcome by means of his diagonal science. Caillois stands at the beginning of a "transhuman" thinking that will also later appear in the philosophy of Gilles Deleuze. In this context, Michelle Richman (1988) has pointed out that the group of renegade surrealists around Roger Caillois and Georges Bataille in the 1930s are „postructuralists avant la lettre“.

24. Peter Berz, for example, refers to Caillois' theory in arguing for a contemporary approach to a „biological aesthetic theory“: „Das eben begonnene Jahrhundert scheint eine rapide Biologisierung sämtlicher Diskurse in Gang zu setzen. Es gibt also gute Gründe, die tatsächliche und mögliche Lage ästhetischer Reflexion vor dem mächtigen biowissenschaftlichen Wissensdispositiv neu zu überdenken, und zwar weit grundsätzlicher als Biologie und Kunstwissenschaft dies wollen oder können." (Berz: 2008a: 23 und 24). For a more recent Darwinist attempt to combine evolutionary and aesthetic theory, cf. Menninghaus (2011).

\section{ABSTRACTS}

The article focuses on the "mythical" epistemology of Roger Caillois (1913-1987). For the French sociologist, writer and literary critic myth can no longer be confined to the specialist area of a cultural analysis of mythology, but is part of a "diagonal science». In his work Le mythe et l'homme (1938), he aims to develop a "biological" basis for the theory of myths. He argues that human imagination is dominated by instincts and that natural processes control cultural production. Thus, Le mythe et l'homme combines anthropology with biology. But this heretical combination of different fields of research is not strictly speaking "scientific", but rather creates, even against the intention of its author, a quasi-mythological text itself. Still, my reading of Caillois' biologist mythology proposes to consider this text not as simply pseudo-scientific, but as a hybrid between fiction and science and in this sense as epistemologically productive: It aims to revitalise the realm of aesthetics by drawing on seemingly more objective biological paradigms. But by doing so, Caillois at the same time turns concepts of evolutionary biology upside down and reorganizes them according to aesthetic criteria. I.e., Caillois' approach to a biology of myth is still an inspiring incentive to further pursue analyses of the links between evolutionary and aesthetic theory.

Ce texte montre la fécondité d'une épistémologie "mythique » telle que celle de Roger Caillois (1913-1978). Pour le sociologue et écrivain, le mythe n'est pas l'objet d'une science spécialisée (la mythologie), mais contribue au projet d'une «science diagonale " qui excède et transgresse les différentes disciplines scientifiques. Dans son ouvrage fondateur Le mythe et l'homme (1938), Caillois rapporte les mythes à une base biologique : en posant que l'imagination de l'homme est dominée par son instinct et, donc, la production culturelle par des phénomènes naturels, il «diagonalise» l'anthropologie et la biologie. Mais cette combinaison hérétique des sciences 
aboutit moins, malgré la volonté de Caillois, à une mythologie scientifique qu'à un texte luimême mythique. Sans manquer de critiquer ses failles, cet article montre que cette «mythologie biologiste» n'est cependant pas «pseudo-scientifique», mais forme un hybride épistémologiquement productif entre la fiction et la science. Caillois vivifie le domaine de l'esthétique en avançant des paradigmes apparemment plus objectifs. Mais en même temps, il renverse les concepts de la biologie évolutionniste et les réorganise selon des critères esthétiques. Son approche d'une biologie du mythe incite ainsi à poursuivre l'analyse stimulante des liens entre esthétique et évolutionnisme.

INDEX

Mots-clés: mythe, surréalisme, Caillois (Roger), biologie, esthétique

Keywords: myth, biology, Caillois Roger, surrealism, aesthetics 